\title{
Спортивна дієтологія та перспективи ії̈ викладання у вузах фізичного виховання і спорту
}

\author{
О. І. Циганенко, С. М. Іващенко, Н. А. Склярова
}

Національний університет фізичного виховання і спорту України, Київ, Україна

\begin{abstract}
Резюме. Разработана программа преподавания спортивной диетологии в вузах физического воспитания и спорта, которая включает лекции и практические занятия, а также вопросы для самостоятельной работы студентов. В программу входят положения по задачам спортивной диетологии, основные направления ее применения для обеспечения подготовки спортсменов, вопросы практического использования спортивных диет для сохранения и повышения физической работоспособности спортсменов, положения по применению лечебно-профилактических и лечебных диет, вопросы эргогенической диететики, системы применения спортивных диет. Программа введена в учебный процесс в Национальном университете физического воспитания и спорта Украины на уровне подготовки магистров.
\end{abstract}

Ключевые слова: диетология, диета, спорт, питание.

Summary. Program of teaching sports dietology in physical culture and sport institutions, including lectures and practice as well as questions for independent work of students, has been developed. The program includes provisions concerning sports dietology tasks, main directions of its application for provision of athletes' preparation, issues of practical usage of sports diets for maintenance and improvement of physical work capacity of athletes, provisions referring to application of medical and preventive diets, issues of ergogenic dietetics, systems of sports diet usage. The program has been introduced in educational process of National University of Physical Education and Sport of Ukraine at the level of master preparation.

Key words: dietology, diet, sport, nutrition.

Постановка проблеми, аналіз останніх публікацій. Дієтологія (грец. diaita - спосіб життя, режим харчування і logos - наука) - це наука про дієти та їх застосування в харчуванні сучасної людини, насамперед хворої, у класичному визначенні даного поняття [4, 6, 10 ].

Поняття (термін) «дієта» застосовують у сучасній дієтології (гігієні харчування) для визначення спеціальних раціонів харчування, які складаються відповідно до поставленої мети та завдань практичного використання. Це стосується таких видів дієт, як лікувальні (клінічні), лікувально-профілактичні, спортивні підтримуючого типу (для проведення тренувань спортсменів, хворих на хронічні захворювання), а також спортивних дієт для підготовки спортсменів. При використанні дієт до їх основних характеристик додають ще й показання до їх застосування. Як правило, дієти застосовуються за призначенням лікаря-дієтолога $[4,6,10,11,13]$.

Харчовий раціон - це добова кількість їжі та іiї асортимент, які повинні задовольняти добові потреби сучасної людини. Поняття харчовий раціон $€$ основним поняттям гігієни харчування, проте достатньо широко використовується і в сучасній дієтології [4, 11].

Нині з'явився новий напрямок дієтології, який визначається як харчування здорової людини. До нього відноситься і спортивна дієтологія $[4,11]$.

Основними завданнями дієтології здорової людини $€$ підвищення стійкості організму до різних негативних чинників оточуючого середовища, у тому числі фрізичних і психічних навантажень, недостатності кисню в умовах високогір'я, до високих та низьких температур, зміни часових поясів тощо. За аналогією з фармакологією здорової людини цей напрямок визначають як «бойову» дієтологію, оскільки він крім спорту використовується ще й у військових та охоронних структурах $[4,10,11]$.

Спортивна дієтологія - відносно нова наука, яка $є$ розділом дієтології. Згідно з потребами спорту та фрізичної культури першочерговим завданням спортивної дієтології $\epsilon$ підвищення фрізичної працездатності людини, стійкості до 
відомих за обсягом та інтенсивністю фрізичних навантажень [8, 10].

Положення сучасної спортивної дієтології знайшли достатньо широке застосування у практиці спорту, проте не розроблена програма ії̈ викладання у вузах фрізичного виховання та спорту, що робить таку розробку актуальною.

Мета дослідження - на основі аналізу джерел наукової інформації розробити програму викладання спортивної дієтології у вузах фрізичного виховання і спорту.

Методи та організація дослідження. Відповідно до поставленої мети було проведено системний аналіз наукової літератури. На його основі сорормовано положення програми викладання спортивної дієтології у вузах фрізичного виховання і спорту. При проведенні досліджень використовувалися методи теоретичного аналізу літератури: узагальнення, синтез, фрормалізація, абстрагування [1].

Результати дослідження та їх обговорення. При розробці навчальної програми було враховано, що в сучасній спортивній дієтології для збереження та підвищення фрізичної працездатності спортсменів існують два напрямки: використання спортивних дієт (основний) та ергогенічна або ергогенна (грец. еrgo - робота, gen - народжуючий) дієтетика (додатковий) $[7,8,10]$.

Ергогенічна дієтика використовується для цілеспрямованої дії на ключові реакції обміну речовин в організмі. Фактори харчування та фрармакологічні засоби застосовують як харчові добавки для підвищення фрізичної працездатності спортсменів. Основні положення (принципи) ергогенічної дієтетики мають на меті не досягнення високих органолептичних якостей харчування, а ефективну дію на ті біохімічні процеси в організмі, які лімітують фрізичну працездатність. Залежно від притаманної їм біохімічної природи чинники ергогенічної дієтетики з вираженою біологічною дією поділяють на такі групи: субстрати (основні нутрієнти), активатори та інгібітори обміну речовин (вітаміни та мікроелементи), недопінгові анаболіки (ендогенні та екзогенні), адаптогени, антиоксиданти та антигіпоксанти, а також засоби ергогенічної (ерогенної) дієтетики. Вони використовуються у формі дієтичних добавок (ДД - згідно з термінологією, прийнятою в Україні), біологічно активних добавок (БАД згідно з термінологією, прийнятою в Російській Федерації) та продуктів підвищеної біологічної цінності (ППБЦ) $[3,5,9,10]$.

Основним завданням ергогенічної дієтетики $\epsilon$ покращення фрізичної та психічної підготовки спортсменів. Розгляду цього питання в навчальній програмі присвячена лекція. Як приклад використання на практиці ергогенічної дієтетики наведемо, що достатньої популярності серед спортсменів-плавців набув як ергогенний засіб ергогенічної дієтетики креатінмоногідрат та ін. $[7,10]$.

За своїми властивостями, насамперед за віднесенням до неї ДД (за термінологією Росії БАД), ергогенічна (ергогенна) дієтетика схожа зі спортивною фрармакологією. У свою чергу доповнення раціонального харчування ергогенічними чинниками наближає ергогенічну дієтетику до раціонального харчування спортсменів, а доповнення ергогенічними чинниками спортивних дієт - до спортивної дієтології $[8,10]$.

У спортивній дієтології для підвищення фрізичної працездатності спортсменів широко використовують спортивні дієти - як різновид дієт для здорової людини $[8,10]$. Застосовують їх за двома основними напрямками (методологічними підходами), а саме у вигляді систем елементної та дієтної $[4,10]$.

Елементна система передбачає розробку індивідуальної спортивної дієти для покращення підготовки спортсменів відповідно до поставленої мети та завдань. Для цього розраховують енергетичну цінність та хімічний склад дієти, режим та термін іiї застосування з урахуванням програми тренувального процесу. Таку роботу виконує спортивний дієтолог, а за його відсутності - спортивний лікар, який використовує комп'ютерні програми оцінки та корекції харчування, котрі дозволяють проводити збалансування дієти на всіх трьох рівнях збалансованості (базовому, розширеному та додатковому). Елементна система більш досконала, проте складна для розробки та використання, тому застосовується на практиці тільки для спортсменів високої кваліфрікації $[4,10]$.

Дієтна система (раніше - групова) передбачає використання вже розроблених стандартних дієт для покращення підготовки спортсменів, які наведені у відповідних публікаціях $[4,10]$.

Кожна спортивна дієта та ії варіанти, крім показань до використання, характеризується вимогами до $[4,10]$ :

- енергетичної цінності та хімічного складу;

- режиму харчування;

- виду кулінарної обробки харчових продуктів;

- переліку дозволених (рекомендованих) до використання страв.

Застосування на практиці спортивних дієт для підготовки спортсменів передбачає використання двох систем «ступінчастої» та «зигзагів» $[4,10]$. 
«Ступінчаста» система - це поступове розширення дієти 3 метою покращення підготовки спортсменів, або навпаки ії̈ звуження (за енергетичною цінністю та складом нутрієнтів) до рівня раціонів раціонального харчування спортсменів $[4,10]$.

Система «зигзагів» - це короткострокове та періодичне («зигзагом») використання спортивної дієти для покращення підготовки спортсменів $[4,10]$.

Виділяють також контрастні спортивні дієти для покращення підготовки спортсменів, які набули достатнього поширення у практиці спортивної дієтології. Контрастні спортивні дієти бувають навантажувальні - «плюс зигзаги» та розвантажувальні - «мінус зигзаги» [4, 8, 10].

Розвантажувальні дієти можуть бути визначені за показником енергетичної цінності або за показниками складу та кількості нутрієнтів, наприклад вуглеводів, або за тим й іншим. Так, до розвантажувальних дієт належить зональна спортивна дієта з обмеженням у ній вмісту вуглеводів. Вона використовується спортсменами-плавцями, оскільки показано, що неадекватно великі запаси вуглеводів в їхньому організмі погіршують спортивні результати. Проте в спортивній практиці найбільшої популярності набули розвантажувальні дієти зі зменшеною енергетичною цінністю. Як приклад, за рахунок такої дієти добове надходження енергії з їжею для спортсменів-двоєборців можна зменшити з 6000 до 1800-2000 ккал $[7,10]$.

Популярні розвантажувальні дієти (як за показником енергетичної цінності, так і показниками кількості певних нутрієнтів), наприклад, у спортсменів легковаговиків (рульові) в греблі академічній [8, 10].

Навантажувальні спортивні дієти для покращення підготовки спортсменів включають до харчування періодично, за певними схемами. Основне призначення таких дієт - це різке підвищення функціональних спроможностей організму або нарощування маси м'язів. Дієти з підвищеним вмістом вуглеводів практикуються серед спортсменів, які працюють на витривалість, наприклад «важковаговиків» в греблі академічній. Стосовно них використовуються також дієти 3 підвищеним вмістом білків для нарощування маси м'язів. Особливо популярні навантажувальні спортивні дієти для нарощування маси м'язів серед спортсменів силових видів спорту $[8,10]$.

$€$ і змішані спортивні розвантажувально-навантажувальні дієти для покращення підготовки спортсменів, такі, наприклад, як тайпер. Коли спочатку призначається розвантажувальна дієта зі значно зниженим вмістом вуглеводів, а потім дієта з високим вмістом вуглеводів, що в результаті призводить до підвищення вмісту глікогену у м'язах та печінці $[7,8,10]$.

Що стосується лікувально-профрілактичної дієт для спортсменів, то вони включають набір продуктів специфічної спрямованості для зменшення токсичної дії хімічних речовин, наприклад у мотоциклетному спорті (закриті приміщення) $[8,10]$.

Згідно з тактикою сучасної дієтотерапії при застосуванні лікувальних дієт у практиці спорту (насамперед за умов клініки) призначають режим щадний (перший напрямок) або тренування (другий напрямок). Перший найчастіше використовують на початку лікування, другий реалізується за «ступінчастою» системою, або за системою «зигзагів». Використовують також лікувальні дієти за М. І. Певзнером, лікувальні дієти з різною енергетичною цінністю і та ін.

Лікувальні дієти використовуються і при дієтотерапії патологічних станів, при синдромі «спортивного» серця тощо $[8,10]$.

Підтримуючі спортивні лікувальні дієти займають проміжне положення між спортивними та лікувальними дієтами. Їхнє основне завдання надати можливість спортсменам, хворим на хронічні захворювання, насамперед на діабет II та I, займатися тренуваннями за умов значних фрізичних навантажень [7, 12].

Для роботи зі складання, оцінки та корекції дієт (у тому числі й спортивних) дієтологи використовують спеціальні комп'ютерні програми типу «Дієта» (Росія, Інфрормаційний центр системного аналізу РАН Росії). Вони дозволяють складати дієти з урахуванням віку, статі, зросту, маси тіла, стану здоров'я пацієнта тощо та відповідно до конкретних завдань подальшого використання дієт проводити корекцію дієт та визначати ефеектиність їх застосування. Для практичної реалізації цих положень створюються профрільні дієтологічні кабінети з відповідним обладнанням для їх роботи. У таких кабінетах працює лікар-дієтолог [8].

Програма викладання спортивної дієтології у вузах фрізичного виховання і спорту в цілому включає дві лекції та чотири практичних заняття, а також положення для самостійної (поза аудиторної) роботи студентів. Програма введена у викладацький процес у Національному університеті фрізичного виховання і спорту на рівні підготовки магістрів.

Висновки. Спортивна дієтологія достатньо поширена, складна у використанні, тому доцільно 
проводити викладання її як курсу в університетах фрізичного виховання і спорту на рівні магістратури.

\section{Література}

1. БаскоВ А. Я. Методология научного исследования/ А. Я. Басков, Н. В. Туленков. - К.: МАУП, 2004. - 215 с.

2. Волков В. М. Биологически активные добавки в специализированном питании спортсменов / В. М. Волков, В. И. Олейников. - М.: Здоровье человека, 2001. - 79 с.

3. Гунина Л. М. Фармакология спорта/ Л. М. Гунина, С. А. Олейник, Р. Д. Сейфулла. - К.: Олимп. лит., 2010. $640 \mathrm{c.}$

4. Диетология. Руководство / под ред. Ю. А. Барановского. - Спб.: Изд-во Питер, 2013. - 1024 с. - (Сер. Спутник врача).

5. Допинг и эргогенные средства в спорте/ под общ. ред. В. Н. Платонова. - К.: Олимп. лит., 2003. - 576 с.

6. Эвенштейн 3. М. Популярная диетология/ З. М. Эвенштейн. - М.: Изд-во Экономика, 1990. - 321 с.

7. Питание спортсменов. Руководство для профессиональной работы с физически подготовленными людьми/ под ред. Кристин А. Розенблюм. - К.: Олимп. лит., 2006. 535 c.

8. Потребительский портал Мy - Drinks. Org. Новости. Диетология в фритнесе и спорте [Электронный ресурс] // Режим доступа:www: my drinks. Org. ua/ru/novosti.

9. Сарубин Э. Популярные пищевые добавки / Э. Сарубин. - К.: Олимп. лит., 2005. - 479 с.

10. СпортиВная фармакология и диетология/ под ред. С. А. Олейника, Д. М. Гуниной. - М.: ООО «И. Д. ВильямС», 2008. -256 с.

11. Тутельян В. А. Научные основы здорового питания/ В. А. Тутельян. - М.: Изд. дом «Панорама», 2010. $816 \mathrm{c}$.

12. Burke L. Clinical sports nutrition / L. Burke, V. Deakin. - Sydney; N. Y. McGraw. - Hill, 2006. - 882 p.

13. Cooking for Special Diets. The Culinary Institute of America (CIA). - N. Y.: John Sons incorporated, 2014. $370 \mathrm{p}$.

sportmedkaf@yandex.ru
Розроблена програма викладання спортивної дієтології у вузах фрізичного виховання і спорту.

\section{References}

1. Baskov A. Y. Methodology of scientific study / A. Y. Baskov, N. V. Tulenkov. - Kiev: MAUP, 2004. - 215 p.

2. Volkov V. M. Biologically active supplements in specialized nutrition of athletes / V. M. Volkov, V. I. Oleynikov. Moscow: Zdorovye cheloveka, 2001. - 79 p.

3. Gunina L. M. Sports pharmacology/ L. M. Gunina, S. A. Oleynik, R. D. Seyfulla. - Kiev: Olimpiyskaya literatura, 2010. -640 p.

4. Dietology. Manual / ed. by Y. A. Baranovsky. - Saint Petersburg: Piter Publishing House, 2013. - 1024 p. - (Ser. Sputnik vracha).

5. Doping and ergogenic means in sport/ Edited by V. N. Platonov. - Kiev: Olimpiyskaya literatura, 2003. 576 p.

6. Evenstein Z. M. Popular dietology/Z. M. Evenstein. Moscow: Ekonomika Publishing House, 1990. - 321 p.

7. Nutrition of athletes. Manual for professional work with physically prepared persons / ed. by Christine A. Rosenblum. - Kiev: Olimpiyskaya literatura, 2006. - 535 p.

8. Consumer's portal My - Drinks. Org. News. Dietology in fitness and sport [Electronic resource] // Access mode:www: my drinks. Org. ua/ru/novosti.

9. Sarubin E. Popular nutrition supplements / E. Sarubin. - Kiev: Olimpiyskaya literatura, 2005. - 479 p.

10. Sports pharmacology and dietology/ edited by S. A. Oleynik, D. M. Gunina. - Moscow: 000 «l. D. Wiliams», 2008. - 256 p.

11. Tutelian V. A. Scientific bases of healthy nutrition/ V. A. Tutelian. - Moscow: «Panorama» Publishing House, 2010. -816 p.

12. Burke L. Clinical sports nutrition / L. Burke, V. Deakin. - Sydney; N. Y.: McGraw. - Hill, 2006. - 882 p.

13. Cooking for Special Diets. The Culinary Institute of America (CIA). - N. Y.: John Sons incorporated, 2014. $370 \mathrm{p}$.

Надійшла 17.11.2014 